\title{
Micheal Silagi*
}

\section{The Preamble of the German Grundgesetz-Constitutional Status and Importance of Preambles in German Law}

\begin{abstract}
Generally, normative acts are passed without preambles in Germany. The federal Basic Law of 1949 , like the Weimar Constitution of 1919 , however, did contain a preamble, which has been modified in 1990, upon German reunification. The predominant view on that preamble minimizes its importance for the interpretation of the operative sections of the Grundgesetz. Until 1990, the only normative directive read into the preamble by the Constitutional Court was the precept of the reunification of Germany. According to most authorities on constitutional law, the introductory reference to God (nominatio or invocatio dei) has no legal connotation whatsoever.
\end{abstract}

Keywords: proems to normative acts-nature and legal relevance, preambles in German legislation, the 1949 and 1990 preambles to the Grundgesetz, the precept of reunification of Germany as a normative directive before 1990, the reference to God (invocatio dei)

\section{A) Introduction}

Preambles, i.e. prologues or prolegomena, to operative parts of legislation take different shapes, and legislators pass normative acts together with such preliminary sections for quite different reasons. ${ }^{1}$ Constitutional preambles might include references to the historical or political circumstances leading to the making or to the amending of a constitution. They might identify the bearers of the constituent power with respect to a particular territorial entity, or epitomize the political and moral conceptions of the drafters of the new codification. As will be seen, both versions of the preamble to the German Basic Law (the preamble of 1949 and the revised version of 1990, replacing the original wording upon German reunification) are very much related to the legal circumstances and political conditions leading to their adoptions at the resepctive date of their origin. Especially the original preamble of 1949 , but, albeit to a lesser extent, the preamble of 1990 , were also intended to point to the future.

Whereas the federal consitution of Germany, i.e. the Basic Law, as well as 14 out of the 16 constitutions of the federated Laender of Germany contain preambles, ordinary legal acts drafted after 1949, only rarely are preceded by introductory sections. Only statutory instruments (so-called "Verordnungen"), shall, according to article 80 of the German Basic Law, contain an introductory statement of their legal basis. ${ }^{2}$

* Professor, Senior Research Fellow, Institute of International and European Law, University of Göttingen, D-37073 Platz der Göttinger Sieben 5, Göttingen.

E-mail: intecolaw@gwdg.de

${ }^{1}$ On preambles in general see Fögen, M. T.: Das Lied vom Gesetz. Munich, 2006; Siedentopf, H.-Huber, N.: Präambeln, Vorsprüche und Zweckbestimmungen in den Rechtsordnungen der westlichen Welt. In: Hermann, H. (ed.): Gesetzesvorspruch. 1988, 37; Varga, Cs.: The Preamble: A Question of Jurisprudence. Acta Juridica Hungarica, 13 (1971), 101.

2 Cf. Papenheim, A.: Präambeln in der deutschen Verfassungsgeschichte seit Mitte des 19. Jahrhunderts. Doctoral thesis, Münster, 1998, passim. 
In other legal orders, introductory sections of ordinary legal acts frequently refer to the normative or constitutional basis of the particular act in superior legal norms, or they give reasons for or justify that act of legislation. Such references and justifications preceding the operative part of a law are known from the EU regulations or directives according to art. $296 \mathrm{TFEU}^{3}$ and they are commonly applied, e.g. in Spain, in the UK and the USA. In Germany, if the legislator deems it appropriate to give reasons for or justify his particular act of legislation, one ore more articles will be included in the operative part of the law, usually in an introductory section, holding so-called "Leitvorschriften", i.e. guiding rules. And even in the few cases where a preamble has preceded a legal act in German legislation since 1949, the operative articles of that act contained additional guiding rules, stating the purpose of legislating or containing definitions.

\section{B) Preambles in German legislation}

In the Federal Republic of Germany, the legislator's general dislike of proems to normative acts may be explained with the preceding practice of the Third Reich and the practice of the German Democratic Republic and, possibly, also with an aversion to the legislation of the authorities of the Allied Forces occupying Germany, Allied directives frequently including detailed introductory sections on the purpose and scope of a particular act. In the Third Reich and, to some extent, also in the German Democratic Republic, preambles to laws were quite a costumary way of informing the public of the ideological basis for and, thus, a manner to determine the content of a normative rule, and they were sometimes of more importance for the interpretation of a concrete act of legislation than the wording of the bill itself. As one author said in 1988, many legal acts passed under National Socialism, were literally opposed with their preambles. Such preambles were sometimes longer than the operative sections and they were deemed to be more closely related to real life and considered as more immediate and, therefore, less questionable manifestations of the will of the legislator. Thus, one could get the impression that the proems were intended to undermine the positive normative rules following. ${ }^{4}$

In spite of the mentioned general dislike of preambles, in exceptional cases, the German legislator, when passing a legal act, still felt it appropriate to make some delcaratory statement and include it by way of an introductory statement, even after 1949. Thus, in the case of the Lastenausgleichsgesetz (Equalisation of Burdens Act) of August 14, 1952, the preamble contained an acknowledgement of the special sufferings of the ethnic German expellees from the East with, however, no practical relevance for the system of equalization of burdens. The preamble was merely meant to be a political statement and it was not a substitute for those "Leitvorschriften", i.e. guiding rules in the first section of the law, especially art. 1, stating the "goals" of the compensatory payments to individuals for losses during and after World War II and the further articles containing definitions.

When, after World War II, the Austrian State regained its independence from the Germany, the authorities of Western Germany and Austria disagreed on the question, if and at what moment legal personality and capacity of Austria had been restored and whether Austrians had lost German citizenship as of April 26, 1945, or at some later date, or not at

3 Art. 253 EC which has been replaced by art. 296 TFEU as of Nov. 1st, 2009, has been analyzed by Naumann, K.: Eine religiöse Referenz in einem Europäischen Verfassungsvertrag. Tübingen, 2008, $115-117$.

4 Siedentopf: op. cit. 42. 
all. When regulating the loss of German citizenship by Austrians in 1956, the German legislator deemed it appropriate to state the official German legal point of view concerning the fate of the Austrian State in 1938 in a preamble to that act. According to that preamble the German Act of 1938 on Reunification of Austria and Germany had been valid at the time it was enacted, and it had only ceased to be in force at the end of World War II. Thus, Germany explicitly disagreed with the Austrian position, claiming that the law declaring the "Anschluß" had been void ab initio. ${ }^{5}$

\section{C) The Constitutional Preamble}

While ordinary laws generally were passed without preambles in the Federal Republic of Germany after 1949, the federal Basic Law of 1949, like the Weimar Constitution of 1919, contained a preamble-as do, according to an Austrian scholar, 143 out of 191 contemporary constitutions worldwide. ${ }^{6}$ The original preamble to the Grundgesetz had the following wording: "The German People in the Laender Baden, Bavaria, Bremen, Hamburg, Hesse, Lower Saxony, Northrhine-Westphalia, Rhineland-Palatinate, Schleswig-Holstein, Wuerttemberg-Baden and Wuerttemberg-Hohenzollern, conscious of its responsibility before God and Men, animated by the resolve to preserve its national and political unity and to serve the peace of the World as an equal partner in a united Europe, desiring to give a new order to political life for a transitional period, has enacted, by virtue of its constituent power, this Basic Law of the Federal Republic of Germany.

It has also acted on behalf of those Germans to whom participation was denied.

The entire German people is called on to achieve in free self-determination the unity and freedom of Germany."

After World War I, in the Case of the 1919 Constitution, it was the general view that the preamble contained only some delcaratory remarks concerning freedom, justice, peace and progress. As Hermann von Mangoldt has stressed in his monograph explaining the Basic Law, "under the present circumstances", i.e. the situation of the year 1949, the significance of the introductory remarks to the Basic Law must be viewed quite differently, having regard to certain aspects of the history of origin of the Grundgesetz (von Mangoldt was the leading public law expert among the CDU-members of the Parliamentary Council, whose members, from September 1, 1948, to May 8, 1949, were drafting the Grundgesetz basing themselves on proposals of the Council of Experts convened in Herrenchimsee in August 1948).

The legal moment of those introductory remarks, i.e. of the preamble to the Grundgesetz, could, of course, not be predicted when passing the Basic Law in 1949. One reason is the unforeseeable future state of Germany. Another aspect should be mentioned, too: According to the German Grundgesetz, the Federal Constitutional Court was and still is to be the Court of last (and in most cases also of first) instance in all questions concerning the authentic interpretation of the Grundgesetz and of judiciary review, and it is considered by some authors to be the equivalent of a permanent constitutional assembly. However, it cannot be doubted that the drafters of the preamble to the Basic Law in the Bonn

5 Cf. Hailbronner, K.-Renner, G.-Maaßen, H.-G.: Staatsangehörigkeitsrecht. 5th ed., Munich, 2010, 2. StAngRegG marginal no. 2.

${ }^{6}$ Schambeck, H.: Verfassungsrecht, Religion und Geschichte. In: Kohl, G.-Neschwara, Ch.-Simon, T. (eds): Festschrift für Wilhelm Brauneder. Vienna, 2008, 469, 474.

7 von Mangoldt, H.: Das Bonner Grundgesetz. 1st ed., Berlin, 1953, 29. 
Parliamentary Council, wanted their constitution to be read and interpreted subject to certain provisos, based on the special circumstances of post-war Germany, which should be included in a preamble.

\section{The Situation of 1949 mirrowing in the Preamble to the Grundgesetz}

In 1948/49, it was the Western Allied Powers, who suggested to the Laender of the American, British and French zones of occupation to form a federal West German State. Its constitution should be drafted by a constituent assembly elected by the people in the several Laender and it should then be ratified by the Military Governors. Finally, it was to be submitted to popular vote and it was supposed to enter into force upon being accepted by a simple, though not qualified, majority of voters in at least two-thirds of the Laender.

The offer of the Western Allies to support the foundation of a West German Federation was considered to be a mixed blessing by the Laender. The Minister-Presidents, i.e. the heads of Laender governments, got into a state of conflict: There was the real danger that a State limited to the Western Zones of occupied Germany would further deepen the division between East and West. The Laender Prime Ministers accepted the offer of the Western allies albeit only with important reservations. The federal State to be established by the Laender in the Western Zones of Germany should be set up as a transitory entity and it should cease to exist upon Germany regaining its unity. Therefore, the assembly drafting the Constitution of that provisional State was not to be a constituent assembly elected by the people at large, but it was rather conceived as a Parliamentary Council, whose members were to be elected by the parliaments of the several Laender. The constitutional draft presented by that Parliamentary Council should not be submitted to popular vote as suggested by the Allied Powers; instead of being accepted by the people at large it should by ratified by a qualified majority of the Parliaments of the Laender involved in the drafting process. And to make it clear that the new fundamental law of the provisional federal State to be established was supposed to be provisional or transitional as well, that act was to be called Basic Law (Grundgesetz) instead of Constitution (Verfassung). In the beginning of the drafting process it was planned to conceive the Basic Law merely as an organisational statute of an occupied country. The Parliamentary Council wanted the preamble to the Basic Law, among others, to mirror the special circumstances of occupation, and the Council had therefore intended to adopt the following reference in the preamble to the limitations imposed upon the independence of the Federal Republic by the occupying powers: "The occupation of Germany by foreign powers has subjected the exercise of the right [to the free formation of national life] to severe limitations."

At a later stage, the General Drafting Committe of the Parliamentary Council, however, thought that a preamble stressing the restrictions to sovereignty caused by the Allied occupation would sound too much like resignation, and, finally, they avoided any mention in the Basic Law of the occupation regime and the legal relationship of the German lawmaker to it. The historical circumstances of 1948/49 were, rather on the contrary, even veiled by the final draft of the preamble: Though the members of the Council drafting the Grundgesetz were neither chosen by immediate popular election nor did they submit the Grundgesetz to a popular referendum, the preamble stated that "the German People in the [enumerated] Laender, has enacted, by virtue of its constituent power, this Basic Law of the Federal Republic of Germany." When the drafting process of the Basic Law was completed, the fundamental law for Federal Germany was, therefore, no longer considered as just an 
organisational statute of an occupied country. It had, rather, in the Words of the Constitutional Court, "ultimately assumed the guise of the constitutional charter of a sovereign state".

With respect to the unforeseeable future, the Parliamentary Council had been very fortunate to drop its complaints for the lack of sovereignty and not to stress in the preamble to the Basic Law that, in 1949, the Parliamentary Council lacked self-determination and, therefore, could not pass a constitution proper. In 1990, those voices that were stressing the provisional character of the Grundgesetz of 1949 by referring to the preamble, and, upon reunification, were therefore pleading for its replacement by a genuine constitution for the whole of Germany, could easily be ignored. Upon reunification of the divided State of Germany in 1990, it would have been, however, much more difficult to refrain from drafting a genuine new constitution, had there been any explicit reservation in the original draft of the Grundgesetz, as to the lack of of German sovereignty in 1949.

Besides the dropped proviso concerning the lack of sovereignty of the entity to be called Federal Republic of Germany, the Parliamentary Council, when drafting the Grundgesetz, wanted several provisos to be included in its preamble. According to von Mangoldt ${ }^{9}$ they were a) the right of the German people to self-determination, b) German unity, c) the enforced territorial limitation of the order to be established to only one part of Germany, i.e. Western Germany, d) the invitation of other, still excluded, parts of Germany to accede to the newly formed State, e) the name of the newly formed entity and f) its relationship to the German Reich, i.e. the question of continuity or State succession, then, under g), the provisional character of the fundamental Law to be passed, and, finally, h) the dropped statement on the lack of sovereignty. Except for the last point, all provisos had been somehow referred to in the Titel of or in the preamble to the Basic Law in 1949.

Already the title "Grundgesetz für die Bundesrepublik Deutschland" ("Basic Law for the Federal Republic of Germany") was meant to be an allusion to the last three provisos and the legal viewpoint of the majority of the members of the Council. The first part, "Federal Republic", replacing "Reich", was to indicate some distance from the Reich, especially the "Third Reich". That "Federal Republic" was used as an attributive noun to qualify Germany, was, of course, also meant as a plea for German unity. But calling the new State "Germany" should first of all demonstrate the identity of the Federal Republic with the Reich. Not only the official name of the Federal Republic, but also the statements in the preamble, according to which the "the German People [...] has enacted, by virtue of its constituent power, this Basic Law" and that the "German People" was "animated by the resolve to preserve its national and political unity", referred to the identity of the Federal Republic with the German Reich that was supposed to be "preserved". Besides calling the constitution "Basic Law", the preamble expressed the desire for a "new order to political life for a transitional period".

The references to the German people and to national and political unity alluded also to three underlying aspects of the situation of divided post-war Germany, which, according to von Mangoldt, had to be taken into account by the preamble to the Grundgesetz. These aspects were the question of German unity, then, the enforced territorial partition, allowing the new order to be established only in the Western parts of Germany, and, finally, the invitation of other, still excluded, parts of Germany to accede to the newly formed State. The 2 nd sentence of the preamble, therefore, declared that the German people, by enacting

\footnotetext{
8 Decisions of the BVerfG, Vol. 1, Part I, Baden-Baden, 1992, 19.

9 von Mangoldt: op. cit., 30.
} 
the Basic Law, "has also acted on behalf of those Germans to whom participation was denied". And the 3rd sentence of the preamble was not only a mere declaration, but it called upon "the entire German people [...] to achieve in free self-determination the unity and freedom of Germany". Though the preamble was silent on and avoided any hint at the infringements of the occupation, this last sentence explicitly adverted to the right of the German people to self-determination as a precondition for the German people to become, as the preamble declared in its first sentence, "an equal partner in a united Europe". Thus, the authors of the Grundgesetz were demanding for the German State equal treatment and nondiscrimination according to the general principles of international law.

\section{E. The Legal Relevance of the Preamble}

The reach of any legal impact of the original preamble could, of course, not be predicted at the time of the passing of the Basic Law in 1949. As mentioned before, it was up to the Karlsruhe Constitutional Court to ascribe material import to the preamble. ${ }^{10}$ And until 1990, the only normative directive read into that preamble by the supreme constitutional judges, was the precept of reunification of Germany. It was their 1957 judgment ordering the dissolution of the Communist Party of Germany (KPD) and thereby forbidding any further activities of the KPD, which is considered to have been the guiding decision concerning the legally binding commitment of all German State organs to reunification.

When the Communist Party was to be dissolved, because it was said to oppose and fight the free democratic basis order established under the Grundgesetz, the attorneys defending the party argued that dissolution of the KPD would impede reunification and would, therefore, violate the Basic Law. In the first headnote of its dissolution order of August 17, 1956, the Court confirmed that the preamble to the Basic Law, though of special political importance, had also legal implications for the State organs. All State organs of the Federal Republic were obliged to aspire "with all strength" German unity and to refrain from actions impeding or making impossible reunification. The dissolution of the KPD was therefore decreed under the resolutory condition of all-German elections, in the case of which a Communist party would be allowed to run again.

The precept of reunification played a role again in the case concerning the Basic Treaty of December 21, 1972 between the Federal Repulic of Germany and the German Democratic Republic initiated by Bavaria. Only after its entry into force, on July 31, 1973, the Court gave an interpretation of that treaty in the light of the reunification precept of the preamble. The treaty was qualified as an inter se agreement between to segments of Germany that were separated from each other not by an international border but by a border similar to that between to West German Laender. If Karlsruhe had handed down that opinion, binding on the State organs of the Federal Republic, before ratification documents had been exchanged between Bonn and East Berlin, the German Democratic Republic would probably have stopped the exchange procedures. Therefore, the German Constitutional Court did not even grant an injunction demanded by Bavaria, but decided ex post, on July 31, 1973.

Except for the precept of reunification with its very limited influence on practical politics, the legal significance of the old preamble can be neglected. But the hazards of interpretation might have led to quite some problems in 1990. At that time a serious

10 A list of the nine decisions of the Constitutional Court having referred to the preamble until 2009 is presented by Hobe, S. In: Berliner Kommentar zum Grundgesetz. Berlin (looseleaf, instalment of December 2009), marginal nos. 150-158. 
discussion took place, as to whether Germany could continue with a Basic Law intended to be provisional. In this connection, along with its preamble, the final article of the old constitution could also be mentioned, where it said that "This Basic Law shall cease to be inforce on the day on which a Constitution adopted by the free decision of the German people comes into force." Read in conjunction with the desire expressed in the preamble "to give a new order to political life for a transitional period", the Constitutional Court could have possibly disagreed with the perpetuation of the Basic Law by transforming it into a regular constitution.

In the end, however, the provisos concerning the transitional and provisional character, which were inserted into the premable of the Grundgesetz in 1949, did not prevent the German legislator to extend the territorial scope of the original Basic Law to the former German Democratic Republic as of October 3, 1990.

\section{F. The New Preamble of 1990}

Upon reunification, some provisions of the Basic Law became out of date, however, and internationally improper. According to the "Two-plus-Four" Treaty of September 12, 1990, terminating the Allied rights and responsibilities for Germany, the existing outer frontiers of the two German States were to be final, and Germany undertook not to raise any further territorial claims. Therefore, art. 23 of the Basic Law of 1949, allowing admission of "other parts of Germany" to the territorial scope of the Basic Law, had to be cancelled. Concerning the preamble, the present order could no longer be conceived as to be meant for a transitional period of time only. According to the "Two-plus-Four" Treaty, there were also no longer any "Germans to whom participation was denied". The new preamble therefore reads:

"Conscious of its responsibility before God and Men,

Inspired by the determination to promote world peace as an equal partner in a united Europe, the German people, in the exercise of their constitutent power, have adopted this Basic Law.

Germans in the Laender of Baden-Wuerttemberg, Bavaria, Berlin, Brandenburg, Bremen, Hamburg, Hesse, Lower Saxony, Mecklenburg-Western Pomerania, NorthrhineWestphalia, Rhineland-Palatinate, Saarland, Saxony, Saxony-Anhalt, Schleswig-Holstein and Thuringia have achieved the unity and freedom of Germany in free self-determination. This Basic Law thus applies to the entire German people."

We have already mentioned that, if at all, the preamble of 1990 was only to a lesser extent intended to point to the future than the original preamble of 1949. Its main importance lies in the delcaratory remarks concerning the territorial saturation of the German State after reunification and concerning the end of the transitional period.

Still, in a decision of 2009, the German Constitutional Court referred to the "determination to promote world peace as an equal partner in a united Europe". Proclaimed in the preamble to the Basic Law. In itself, that statement does, of course, not stipulate any obligations for the State organs taking part in international efforts to develop a closer European Union, but as the Court held on June 30, 2009, in the decision concerning the Lisbon Treaty, the preamble emphasises the "moral basis of responsible self-determination" and, on the other hand, the "willingness to serve world peace as an equal partner in a united Europe". ${ }^{11}$ This willingness becomes operational only, if read in conjunction with the operative clauses of the Basic Law on integration (arts 23, 24, 26). It is these clauses that lend

11 BVerfG, Lisbon Decision of 30 June 2009, marginal no. 222. 
empowerment to the declaration of willingness, declared in the preamble. ${ }^{12}$ Therefore, it is from art. 23.1 of the Basic Law "and its preamble" that follows the "constitutional mandate to realise a united Europe". ${ }^{13}$ Needless to say that the Court could have reached its conlusions as well without any reference to the "determination to promote world peace as an equal partner in a united Europe" as declared by the preamble.

\section{G. "Conscious of its responsibility before God ..."-On the reference to God in the Grundgesetz}

"Conscious of its responsibility before God and Men" (or mankind?) is the initial phrase, one might say the preamble to the preamble, of both the 1949 and the 1990 versions of the introduction to the Basic Law. The preamble to the Weimar Constitution did not refer to God ${ }^{14}$ and also the Herrenchimsee proposal of August 1948 did not yet containing any nominatio dei. ${ }^{15}$ It was only at a late stage of its drafting by the Parliamentary Council that the quoted initial phrase of the Grundgesetz was first included in the preamble. There, "God and Men" as two cumulative points of reference for the reclaimed responsibility of the legislator of the Grundgesetz, were placed next to each other. Technically speaking, the introductory phrase of the preamble does not imply an "invocatio dei", but a "nominatio dei", a mere reference to God. The juxtaposition of God and Men minimizes, of course, the plausibility of any assertion of a specific religious connotation of the reference to God. It is hardly justifiable or arguable, at least as far as the original version of 1949 is concerned, to read more into the two references, made simultaneously and equally, to God and to Men, than a mere demonstration of awareness of the historic situation that led to the drafting of the new Basic Law and a change of consciousness due to the experiences, the German people had made during the years of National Socialism. Therefore, and considering the strict religious and ideological neutrality decreed by several operative articles of the Basic Law (first, by art. 4 on religious freedom, then, by art. 3 paragr. 3 and art. 33 paragr. 3 , explicitly forbidding discrimination for religious or ideological reasons, and, finally, also by art. 140 with regard to religious association), most authorities on the Grundgesetz will agree that the reference to God in the preamble has "no legal connotation". ${ }^{16}$

Still, authors, of course, differ in their interpretations of the invocation of "God" in the preamble, and, notwithstanding the juxtaposition of God and Men, the historic circumstances, and the operative clauses in the Grundgesetz on strict religious neutrality, some constitutional lawyers see it differently. As late as 2009 , one author commenting on the preamble wrote that the invocation of God, though not decreeing a State religion, was meant to refer to the threefold God of Christianity. ${ }^{17}$ The author differentiates between the responsibility before God and that before Men, devoting five times more space to his remarks on God than to

12 Lisbon Decision, marginal no. 222.

13 Lisbon Decision, marginal no. 225.

14 According to Schambeck: op. cit., only 65 out of 143 contemporary constitutional preambles refer to God.

15 On the different proposals concerning a naming of God (nominatio dei) or an invocation of God (invocatio dei) in the Basic Law, cf. Murswiek, D. In: Bonner Kommentar zum Grundgesetz. Heidelberg (looseleaf, instalment of September 2005), Präambel, marginal no. 19-24.

16 Leisner, W. G. In: Sodan, H.: Grundgesetz. Munich, 2009, Präambel, marginal no. 2.

17 See Hillgruber, Ch. In: Epping, V.-Hillgruber, Ch. (eds): Grundgesetz. Munich, 2009, Präambel, marginal no. 7. 
those on Man. That interpretation would bring the God of the German preamble close to that of the Irish and Greek constitutions, the main difference beeing that Germany, of course, has no State Religion, the lack of a State religion beinig explicitly confirmed by art. 140 of the Basic Law.

The predominant view on the preamble, therefore, minimizes the importance of God. In the already quoted monograph of von Mangoldt on the Basic Law any reference to the invocation of God is missing. Von Mangoldt, himself a Christian Democrat, was commenting every other phrase of the preamble, also stressing differences between the Weimar and the Bonn preambles, but he did not even mention the introductory phrase of the Bonn preamble of 1949 concerning the responsibility before God and Men, although, in this point, the Weimar preamble was quite different. In 1991, Dieter Hömig, then member of the Federal Administrative Court, dropped only one sentence on the reference to God, when commenting the preamble of the Basic Law. He wrote that nothing could be drawn from the reference to God and Men but an indication to the "ideological state of the legislators" in $1949 .{ }^{18}$ In 2010, the author, after having served on the bench of the Karlsruhe Constitutional Court, is less harsh, without, however, changing his opinion substantially. According to the 2010 edition of his comment, the reference to God still does not contain any religious or ideological message in the stricter sense. In his view, stressing the responsibility before God an Men, is tantamount to a rejection of all forms of totalitarianism and to confessing a minimum standard of pre-set values. ${ }^{19}$

Hömig's conception of the introductory clause of the preamble seems to be the prevailing understanding of it. That his interpretation is correct, can be seen from the limited or rather non-existing practical relevance of the "nominatio dei" in constitutional jurisdiction. It has not been referred to by the German Constitutional Court, especially in the recent cases concerning religious instruction in East Germany. It has also not been discussed, when the Court had to decide on the question of shop closing hours, where the special protection of Sundays and religious holidays by the Basic Law was affirmed by the Court, or in the case concerning removal of crucifixes from class-rooms. If the appelants in a constitutional complaint (e.g. concerning religious instruction in Brandenburg) argue with the invocation of God in the preamble, the Court dismisses that argument for procedural reasons without referring at all to the invocation in the merits, because no enforceable rights can be drawn by appellants of a constitutional complaint out of the preamble.

As to the several Laender of the Federal Republic of Germany, nine out of the 16 constitutions of the Laender do not refer to God in their preambles at all ${ }^{20}$ (the Constitutions of Saarland and of Schleswig-Holstein do not contain preambles at all)-already before reunification, it was seven out of eleven constitutions, among them the Saarland: Contrary to the French conception of secularism, the constitution introduced in the territory of Saarland, when it was under French control after World War II, contained a preamble with a reference to God. ${ }^{21}$ Upon reintegration into the Federal Republic of Germany, in 1957, the

18 Hömig, D.: Grundgesetz für die Bundesrepublik Deutschland. (Seifert, K.-H.-Hömig, D. eds), 2nd ed., Baden-Baden, 1991, Präambel, marginal no. 2.

19 Hömig: op. cit., 9th ed., 2010, Präambel, marginal no. 2.

20 In Austria, neither the federal constitution nor the basic laws of the federated Laender-with the exception of the preamble to the Tyrolian constitution of 1989-contain references to God. Cf. Moser, M.: Nicht jedem Anfang wohnt ein Zauber inne. Vom B-VG 1920 zur gegenwärtigen Präambeldiskussion. In: Ehs, T. (ed.): Hans Kelsen. Vienna, 2009, 193 (201).

${ }^{21}$ Bosig, R.: Die Verfassung des Saarlandes. Cologne, 2001, 128. 
preamble was removed. On the other hand, the provisional Constitution of Lower Saxony of 1951 and the Constitution of 1993 did not contain a preamble. But in 1994 the representative organs of the Protestants, the Catholics, and of the Jews in Lower Saxony were demanding the inclusion of God into the new Constitution, and they succeeded in collecting 120000 signatures in a popular initiative. Thereupon, the Parliament of Lower Saxony amended the Constitution. An introductory clause, similar to the first part of the prologue to the Grundgesetz, was adopted, proclaiming that "The people of Lower Saxony, conscious of its responsibility before God and Men, has, by their representatives, enacted the following Constitution".

Any invocation of God seems to be of little relevance, however, and moderate as well as orthodox theologians even find it presumptious to have God invoked in a secular constitution. In the fedarated State of Brandenburg, the two Christian Churches themselves agreed on the omission of God from the new constitution..$^{22}$ In 1949, it was, among others, the prominent Protestant Bishop of Berlin, Otto Dibelius, who rejected any reference to God in the Grundgesetz. ${ }^{23}$ In 1990, Wolfgang Ullmann, an outstanding Protestant cleric and East German dissident, deputy of the last Parliament of the German Democratic Republic and, after reunification, till his death in 2004, member of the Bundestag and the European Parliament for the Green Party, had suggested to completely drop God from the preamble of the Federal Basic Law. ${ }^{24}$ Therefore, not only the lack of legal significance should make legislators refrain from referring to God in State Constitutions.

With regard to the missing ideological or religious homogeneity, in Germany and its Laender as well as in most of the other European States, the invocation of God might not prove to be fateful or momentous, but it has created and will create problems, e.g. at present, in Germany, with its Muslim minority. Here, Christian Wulff, now the German President, had appointed the first Muslim State Minister, when he was still head of government of Lower Saxony. When the nominee took her official oath, adding, "so help me God", she was asked what invoking God meant in her case, and she told an astonished audience that she was invoking Allah.

Following the much disputed remarks on integration in the speech held by the German President, Christian Wulff, on October 3, 2010, the discussion on whether there are religious values underlying the order of the Grundgesetz, has become more heated. Only ten days after that controversial speech, on October 13, 2010, Friedrich Wilhelm Graf, a protestant scholar at the Munich University, internationally of great academic repute and of high theological standing, warned of the consequences of "babtizing" the Grundgesetz. ${ }^{25}$ According to Graf, it would be utterly wrong to assert that the Grundgesetz is based on a "Christian-Jewish heritage", the German constitution being the result of enlightened thought. And he cautioned against qualifying or modifying the difference between rights and religion and between rights and morals.

Thus, it seems that respect and esteem for God should make us hesitate to invoke Him carelessly in the secular and profane context of any secular Basic Law or Constitution.

22 Papenheim: op. cit. 163.

23 Murswiek: op. cit. marginal no. 23.

24 Papenheim: op. cit. 123.

25 Wir sollten das Grundgesetz nicht taufen [We should not babtize the Basic Law]. An Interview with Friedrich Wilhelm Graf. Süddeutsche Zeitung, Munich, 13 October, 2010. 